\title{
Sistem Pendukung Keputusan Penentuan Beasiswa Bidikmisi Dengan Menggunakan Metode Simple Additive Weighting (SAW) Di Politeknik Negeri Lhokseumawe
}

\author{
Isaruddin \\ Politeknik Negeri Lhokseumawe
}

\begin{abstract}
Abstrak - Kampus Politeknik Lhokseumawe dalam penentuan golongan UKT (Uang Kuliah Tunggal) yang dilakukan untuk peserta ujian yang telah dinyatakan lulus masih menggunakan sistem manual yaitu dengan melihat dari kriteria yang telah diberikan. Selanjutnya penggolongan yang dilakukan oleh bagian akademik kurang efektif dikarenakan ada peserta yang membayar uang kuliahnya tidak sesuai dengan kondisi peserta tersebut. Untuk itu diperlukan suatu model dan metode yang mampu menyelesaikan persoalan pengambilan keputusan kriteria majemuk. Model Simple Additive Weighting (SAW) merupakan salah satu metode yang cukup efektif dalam perancangan Sistem Pendukung Keputusan berdasarkan kriteria majemuk. Konsep dasar metode $S A W$ adalah mencari penjumlahan terbobot dari rating kinerja pada setiap alternatif calon penerima beasiswa pada semua kriterianya. Metode $S A W$ membutuhkan proses normalisasi matriks keputusan ke suatu skala yang dapat diperbandingkan dengan semua rating alternatif yang ada. Hasil aadalah Nilai yang paling tinggi dianggap sebagai golongan yang paling cocok untuk kondisi peserta yang bersangkutan dalam penyeleksian calon penerima beasiswa Bidik Misi Politeknik Negeri Lhokseumawe.
\end{abstract}

Keywords- Sistem Pendukung Keputusan, Simple Additive Weighting (SAW), Beasiswa Bidik Misi

\section{PENDAHULUAN}

\section{Latar Belakang}

Bidikmisi adalah program bantuan biaya pendidikan yang diberikan Pemerintah melalui Direktorat Jenderal Pendidikan Tinggi (Ditjen Dikti) Kementerian Pendidikan dan Kebudayaan mulai tahun 2010 kepada mahasiswa yang memiliki potensi akademik memadai dan kurang mampu secara ekonomi melalui perguruan tinggi di bawah Kementerian Pendidikan dan Kebudayaan dan Kementerian Agama.Politeknik Negeri Lhokseumawe adalah salah satu perguruan tinggi negeri dibawah Kemdikbud yang mendapat bantuan Bidikmisi.

Program ini mempunyai misi untuk menghidupkan harapan bagi masyarakat kurang mampu dan mempotensi akademik memadai untuk dapat menempuh pendidikan sampai kejenjang pendidikan tinggi dan sering mengalami masalah. Penentuan golongan Uang Kuliah Tunggal sering terjadi kendala dalam menentukan kategori golongan Uang
Kuliah Tunggal sehingga terjadi persoalan-persoalan yang mengakibatkan jumlah uang kuliah yang dibayar tidak sesuai dengan kondisi kehidupan mahasiswa tersebut. Oleh karena itu, diperlukan suatu Sistem Pendukung Keputusan yang dapat membantu bagian akademik dalam menentukan golongan Uang Kuliah Tunggal, dimana kriterianya diambil pada saat pengisian biodata yang dilakukan oleh peserta yang telah dinyatakan lulus. Peserta tersebut hanya dapat mengisi sekali saja biodatanya apabila telah disimpan peserta tersebut tidak dapat melakukan perubahan terhadap biodata yang telah diisi. Sehingga data manipulasi dapat diminimalisasi. Dan keputusan yang didapat sesuai dengan kondisin kehidupan peserta tersebut.

Berdasarkan hal tersebut untuk membantu penentuan dalam menetapkan seorang mahasiswa memperoleh beasiswa Bidikmisi, maka dibutuhkan sebuah sistem pendukung keputusan dengan metode yang dapat digunakan yaitu metode Simple Additive Weighting Method (SAW) dimana metode tersebut dapat mencari suatu alternatif terbaik dari berbagai alternatif berdasarkan kriteria-kriteria yang telah ditentukan. Alternatif terbaik yang dimaksud adalah yang berhak menerima beasiswa Bidikmisi berdasarkan kriteria yang telah ditentukan.

\section{METODE PENELITIAN}

\subsection{Sistem Informasi}

Sistem informasi adalah suatu sistem yang menerima masukan data dan instruksi, mengolah data tersebut sesuai dengan instruksi dan mengeluarkan hasilnya. Selanjutnya definisi lain dari Sistem informasi adalah suatu sistem di dalam suatu organisasi yang mempertemukan kebutuhan pengolahan transaksi harian, mendukung operasi, bersifat manajerial dan kegiatan strategi dari suatu organisasi dan menyediakan pihak luar tertentu dengan laporan-laporan yang diperlukan." Sistem informasi merupakan komponenkomponen yang saling berhubungan dan bekerja sama untuk mengumpulkan, memproses, menyimpan dan menyebarkan informasi untuk mendukung pengambilan keputusan, koordinasi, pengendalian, dan untuk memberikan gambaran aktivitas didalam perusahaan [1].

Dengan demikian, dapat disimpulkan bahwa Sistem informasi sebagai suatu sistem di dalam suatu organisasi yang merupakan kombinasi dari orang-orang, fasilitas, teknologi, media prosedur-prosedur dan pengendalian yang 
ditujukan untuk mendapatkan jalur komunikasi penting, memproses tipe transaksi rutin tertentu, memberi sinyal kepada manajemen dan yang lainnya terhadap kejadiankejadian internal dan eksternal yang penting dan menyediakan suatu dasar informasi untuk pengambilan keputusan.

\subsection{Sistem Pendukung Keputusan}

Sistem Pendukung Keputusan merupakan sistem informasi yang menyediakan informasi, pemodelan dan pemanipulasian data. Definisi lain Sistem pendukung keputusan adalah sistem tambahan, mampu mendukung untuk menganalis data secara ad hoc dan pemodelan keputusan serta berorientasi pada perencanaan masa depan [2].

Sistem pendukung keputusan adalah suatu sistem informasi yang spesifik yang ditujukan untuk membantu manajemen dalam mengambil keputusan yang berkaitan dengan persoalan yang bersifat semi terstruktur untuk meningkatkan pembuatan keputusan. Sistem Pendukung Keputusan dirancang untuk menghasilkan berbagai alternatif yang ditawarkan kepada para pengambil keputusan, karena sebagian besar proses pengambilan keputusan yaitu perumusan masalah, pencarian alternatif telah dikerjakan oleh sistem, maka diharapkan para pengambil keputusan akan lebih cepat dan akurat dalam menangani masalah yang dihadapinya [3].

Secara umum, dapat dikatakan bahwa Sistem Pendukung Keputusan memberikan manfaat bagi para pengambil keputusan dalam meningkatkan efektifitas dan efisiensi kerja terutama dalam pengambilan keputusan. Beberapa manfaat yang ditawarkan oleh Sistem Pendukung Keputusan diantaranya meliputi: (1) Sistem Pendukung Keputusan memperluas kemampuan pengambilan keputusan dalam memproses data/informasi bagi pemakainya; (2) Sistem Pendukung Keputusan membantu pengambil keputusan dalam hal penghematan waktu yang dibutuhkan untuk memecahkan masalah terutama masalah yang sangat komplek dan tidak tersetruktur; (3) Sistem Pendukung Keputusan dapat menghasilkan solusi dengan lebih cepat serta hasilnya dapat diandalkan; (4) Sistem Pendukung Keputusan dapat menyediakan bukti tambahan untuk memberikan pembenaran sehingga dapat memperkuat posisi pengambil keputusan [3].

\subsection{Simple Additive Weighting (SAW)}

Metode $S A W$ merupakan salah metode perankingan dengan mencari penjumlahan terbobot dari rating kinerja pada setiap alternatif dari semua atribut [4]. LangkahLangkah metode $S A W$ adalah sebagai berikut:

1. Pembuatan Matrik Keputusan (X)

Matriks keputusan (X) memuat alternatif dan kriteria

$$
\mathrm{Y}=\left[\begin{array}{ccc}
x_{11} & \cdots & x_{1 n} \\
\cdots & \cdots & \cdots \\
x_{m 1} & \cdots & x_{m n}
\end{array}\right]
$$

Keterangan simbol:

$$
\mathrm{X}=\text { matriks keputusan }
$$

$$
\begin{aligned}
& \mathrm{Xij}=\text { rating kinerja alternatif ke-i terhadap atribut } \\
& \text { ke-j. } \\
& \mathrm{i}=1,2, . . \mathrm{m} \text { merupakan jumlah alternatif } \\
& \mathrm{j}=1,2, . . \mathrm{n} \text { merupakan jumlah kriteria }
\end{aligned}
$$

\section{Normalisasi matrix keputusan (R)}

Proses menormalisasi matriks merupakan proses perhitungan nilai rating kinerja ternormalisasi berdasar jenis atribut (cost atau benefit).

Ket: $r_{i j}= \begin{cases}\frac{x_{i j}}{\operatorname{Max}_{i}} & j i k a \text { jadalah atribut keuntungan } \\ \frac{\operatorname{Min}_{i} x_{i j}}{x_{i j}} & \text { jika jadalah atribut biaya (cost) }\end{cases}$

- $r_{i j}=$ rating kinerja ternormalisasi dari alternatif $A_{i}$ pada atribut $\mathrm{C}_{\mathrm{j}} ; \mathrm{i}=1,2, \ldots, \mathrm{m}$ dan $\mathrm{j}=1,2, \ldots, \mathrm{n}$.

\section{Proses Perangkingan}

Penjumlahan terbobot dari rating kinerja setiap alternatif pada semua atribut. Nilai preferensi untuk setiap alternatif (Vi) diberikan sebagai berikut :

Nilai preferensi untuk setiap alternatif $\left(\mathrm{V}_{\mathrm{i}}\right)$ diberikan sebagai :

$$
V_{i}=\sum_{j=1}^{n} w_{j} r_{i j}
$$

\section{Keterangan:}

$$
\begin{array}{ll}
-\mathrm{Rij} & =\text { rating kinerja ternormalisasi dari alternatif } \mathrm{Ai} \\
& \text { pada atribut } \mathrm{Cj} \\
-\mathrm{i} & =1,2, . . \mathrm{m} \text { merupakan jumlah alternatif } \\
-\mathrm{j} & =1,2, . . \mathrm{n} \text { merupakan jumlah kriteria }
\end{array}
$$

Nilai $V_{i}$ yang lebih besar mengindikasikan bahwa alternatif $\mathbf{A}_{\mathrm{i}}$ lebih terpilih.

\subsection{Beasiswa Bidikmisi}

Bidikmisi adalah program bantuan biaya pendidikan yang diberikan Pemerintah melalui Direktorat Jenderal Pendidikan Tinggi (Ditjen Dikti), Kementerian Pendidikan dan Kebudayaan mulai tahun 2010 bagi calon mahasiswa tidak mampu secara ekonomi dan memiliki potensi akademik baik untuk menempuh pendidikan di perguruan tinggi pada program studi unggulan sampai lulus tepat waktu.

Program ini mempunyai misi untuk menghidupkan harapan bagi masyarakat tidak mampu dan mempunyai potensi akademik memadai untuk dapat menempuh pendidikan sampai ke jenjang pendidikan tinggi serta menghasilkan sumber daya insani yang mampu berperan dalam memutus mata rantai kemiskinan dan pemberdayaan masyarakat.

Politeknik Negeri Lhokseumawe sebagai perguruan tinggi negeri terpilih dibawah Kementrian Pendidikan dan Kebudayaan sebagai salah satu penyelenggara program Bidikmisi yang menyelenggarakan beasiswa setiap tahun 
kepada mahasiswa Politeknik Negeri Lhokseumawe secara selektif sesuai dengan peraturan yang telah ditentukan oleh Bidikmisi pada Politeknik Negeri Lhokseumawe untuk beasiswa tersebut. Untuk mendapatkan beasiswa bidikmisi, calon mahasiswa penerima beasiswa harus memenuhi persyaratan calon penerima bidikmisi untuk mendaftar sebagai berikut:

1. Siswa SMA/SMK/MA/MAK atau bentuk lain yang sederajat yang akan lulus pada tahun 2014;

2. Lulusan tahun 2013 yang bukan penerima Bidikmisi dan tidak bertentangan dengan ketentuan penerimaan mahasiswa baru di masing-masing perguruan tinggi;

3. Usia paling tinggi pada saat mendaftar adalah 21 tahun;

4. Tidak mampu secara ekonomi dengan kriteria:

a. Siswa penerima Beasiswa Siswa Miskin (BSM);

b. Pemegang Kartu Pengaman Sosial (KPS) atau sejenisnya ;

c. Pendapatan kotor gabungan orangtua/wali (suami istri) sebesar-besarnya Rp3.000.000,00 per-bulan. Pendapatan yang dimaksud meliputi seluruh penghasilan yang diperoleh. Untuk pekerjaan nonformal/informal pendapatan yang dimaksud adalah rata rata penghasilan per bulan dalam satu tahun terakhir;

d. Pendapatan kotor gabungan orangtua/wali dibagi jumlah anggota keluarga sebesar-besarnya Rp750.000,00 setiap bulannya;

5. Pendidikan orang tua/wali setinggi-tingginya S1 (Strata 1) atau Diploma

6. Berpotensi akademik baik berdasarkan rekomendasi kepala sekolah.

7. Pendaftar difasilitasi untuk memilih salah satu diantara PTN atau PTS dengan ketentuan:

a. PTN dengan pilihan seleksi masuk:

1. Seleksi Masuk Perguruan Tinggi Negeri (SNMPTN);

2. Seleksi Bersama Masuk Perguruan Tinggi Negeri (SBMTPN);

3. Seleksi mandiri di 1 (satu) PTN

4. PTS dengan pilihan seleksi masuk di 1 (satu) PTS (Ditjen Dikti, 2014).

\section{HASIL DAN PEMBAHASAN}

Sistem penentuan penerima beasiswa Bidikmisi adalah sistem untuk mengetahui penentuan terbaik untuk pengelola akademik bidang Bidikmisi. Secara umum pendataan ini masih sangat sederhana, selanjutnya Penentuan penerima beasiswa Bidikmisi merupakan suatu hal yang sangat penting karena sering kali terjadi kesalahan dalam menentukan siapa calon siswa penerima beasiswa Bidikmisi yang paling berhak mendapatkan beasiswa tidak sesuai dengan persyaratan yang diberikan oleh Kementrian Pendidikan dan Kebudayaan yang berakibat pensaluran dana yang besar namun tidak memberikan hasil yang diharapkan.

Implementasi Langkah-langkah dalam menyelesaikan metode SAW adalah sebagai berikut:

1. Form Untuk Input Nilai

Form data siswa ini dinputkan oleh admin dan akan digunakan pada form input data pemetaan nilai.

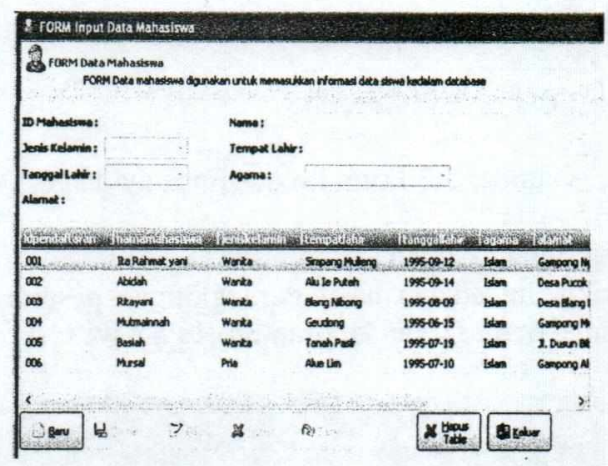

Gambar 3.1 Form Input Data Siswa

\section{Proses Input Pemetaan Nilai}

Form input data pemetaan nilai terdiri dari form pengisian data penilaian siswa, pada form ini data siswa akan diinputkan oleh admin.

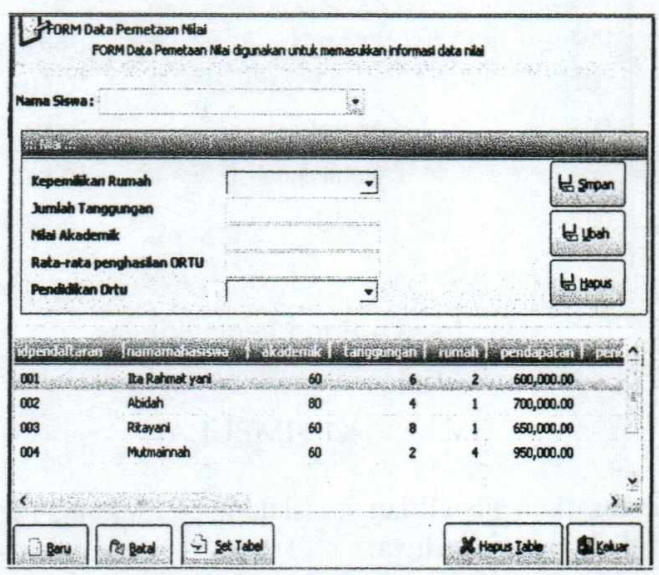

Gambar 3.2 Form Input Data Pemetaan Nilai

\section{Proses Metode SAW}

Berikut ini adalah tampilan dari proses Entropy dan SAW. Form ini menampilkan hasil perhitungan model SAW. 


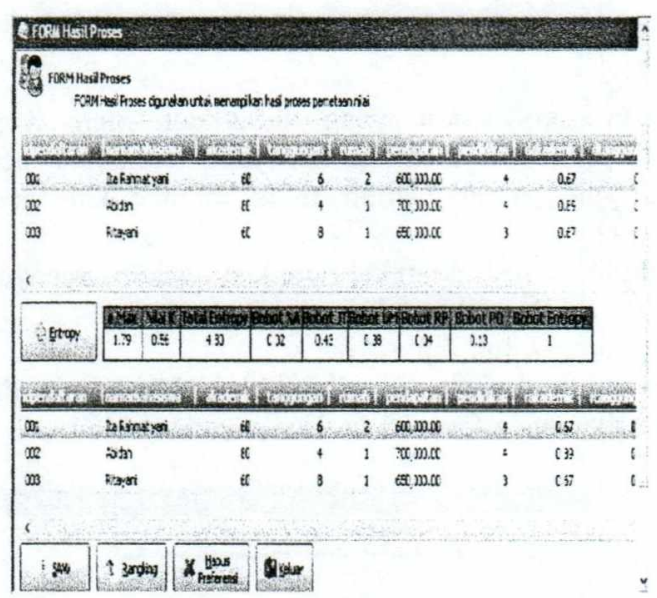

Gambar 3.3 Form Proses Entropy dan SAW

\section{Hasil Perangkingan}

Berikut ini adalah hasil Perangkingan peserta beasiswa bidik misi berdasarkan laporan proses SAW.

\begin{tabular}{|c|c|c|}
\hline \multicolumn{3}{|c|}{ 4. FORH Ranking } \\
\hline & \multicolumn{2}{|c|}{ FORM Ranking } \\
\hline \multicolumn{3}{|c|}{ 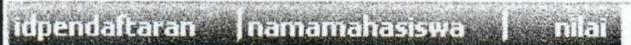 } \\
\hline 005 & Basiah & 0.71 \\
\hline 003 & Ritayani & 0.62 \\
\hline 001 & Ita Rahmat yani & 0.60 \\
\hline 006 & Mursal & 0.59 \\
\hline 004 & Mutmainnah & 0.56 \\
\hline 002 & Abidah & 0.42 \\
\hline
\end{tabular}

Gambar 3.4 Form Perangkingan

\section{KESIMPULAN}

Berdasarkan penelitian ini sistem pendukung keputusan dapat disimpulkan bahwa:

1. Mempermudah dan Membantu pihak akademik dalam menentukan golongan UKT dengan sistem yang lebih efektif dan efisien.

2. Penggunaan sistem ini mempermudah tim panitia penyeleksi beasiswa menetukan kelayakan penerima beasiswa Bidik Misi dan sistem ini mampu mempercepat kinerja panitia seleksi dalam menyeleksi kelayakan penerima beasiswa Bidik Misi.

\section{REFERENSI}

[1] Jogianto, H.M. 2005. Analisis dan Desain Sistem Informasi : Pendekatan Terstruktur Teori dan Praktik Aplikasi Bisnis. Edisi Ketiga. Andi. Yogyakarta.

[2] Kusrini, 2007, Konsep dan Aplikasi Sistem Pendukung Keputusan, Andi, Yogyakarta.

[3] Turban., E., Aronson, J.E., dan Liang, T.P., 2005, Decision Support System and Intellegent System, $7^{\text {th }}$ (Sistem Pendukung Keputusan dan Sistem Cerdas Jilid 1), Dwi Prabantini, Andi Offset, Yogyakarta.

[4] Chu, Mei-Tai, shyu, J., Tzeng, Gwo-Hshiung, Khosla, R., 2007, Comparison Among Three Analytical Methods for Knowledge Communities Group-Decision Analysis, Elsevier. 